\title{
Effects of feeding organic trace minerals on milk production and reproductive performance in lactating dairy cows: A meta-analysis
}

\author{
A. R. Rabiee, ${ }^{* 1}$ I. J. Lean, ${ }^{*}$ M. A. Stevenson, $†$ and M. T. Sochał \\ *SBScibus, PO Box 660, Camden 2570, NSW, Australia \\ †EpiCentre, Institute of Veterinary, Animal, and Biomedical Sciences, Massey University, Palmerston North, New Zealand \\ $\ddagger$ Zinpro Corporation, 10400 Viking Dr., Ste. 240, Eden Prairie, MN 55344
}

\section{ABSTRACT}

The objectives of this meta-analysis were to evaluate the effectiveness of supplementation with the organic trace minerals (OTM; Availa-4 and 4-Plex, Zinpro Corp., Eden Prairie, MN) on milk yield, composition, and component yields and reproductive performance in dairy cows. Twenty research papers and reports on the effects of OTM were considered in this meta-analysis. Criteria for inclusion in the study were information on the form of OTM, an adequate description of randomization, production and reproduction data, and associated measures of variance (SE or $\mathrm{SD}$ ) and $P$-values. The OTM increased milk production by $0.93 \mathrm{~kg}[95 \%$ confidence interval $(\mathrm{CI})=0.61$ to 1.25$]$, milk fat by 0.04 $\mathrm{kg}(95 \% \mathrm{CI}=0.02$ to 0.05$)$, and milk protein by $0.03 \mathrm{~kg}$ $(95 \% \mathrm{CI}=0.02$ to 0.04$)$ per day. Milk SCC was not different in cows supplemented with OTM. All production outcomes except milk solids (yield) and milk SCC were heterogeneous. Meta-regression analysis showed that feeding before calving, feeding for a full lactation after calving, and the use of other supplements increased responses over feeding after calving only, feeding for part of lactation, or not using other supplements, respectively. Supplementation of cows with OTM reduced days open (weighted mean difference $=13.5 \mathrm{~d}$ ) and number of services per conception (weighted mean difference $=0.27$ ) in lactating dairy cows. The risk of pregnancy on d 150 of lactation was greater in cows fed OTM $($ risk ratio $=1.07)$, but OTM had no significant effect on the interval from calving to first service and 21-d pregnancy rate. There was no evidence of heterogeneity for any of the reproductive outcomes evaluated. The results of this meta-analysis showed that organic trace mineral supplementation could improve production and reproduction in lactating dairy cows.

Key words: meta-analysis, dairy cow, organic trace mineral

Received January 5, 2010.

Accepted April 1, 2010.

${ }^{1}$ Corresponding author: ahmadr@sbscibus.com.au

\section{INTRODUCTION}

Although trace minerals comprise less than $0.01 \%$ of the total mass of an organism, they are essential for normal function. Trace minerals are needed for blood synthesis, hormone structure, normal reproductive function, vitamin synthesis, enzyme formation, and immune system integrity. Current National Research Council recommendations for trace mineral concentrations in rations of dairy cattle are formulated on a whole-diet basis. A deficiency of any of these trace minerals may result in impaired function in any of the physiological processes described above. These impairments or abnormalities may be prevented or cured once the deficiency is corrected (NRC, 2001).

Trace minerals from different sources differ in bioavailability. Cattle are often supplemented with trace minerals in the form of inorganic salts; for example, oxides, chlorides, sulfates, and carbonates. In recent years, there has been considerable interest in the use of organic trace minerals (OTM) in ruminant diets. Availa-4 and 4-Plex (Zinpro Corp., Eden Prairie, MN) are 2 products containing a combination of organic zinc, copper, manganese, and cobalt. The $\mathrm{Zn}, \mathrm{Cu}$, and $\mathrm{Mn}$ found in these products are complexed with single AA ligands, whereas the Co is complexed with glucoheptonate. The products differ slightly. In 4-Plex, Zn and Mn are complexed with Met, and $\mathrm{Cu}$ is complexed with Lys, whereas in Availa-4, the AA bound to $\mathrm{Zn}, \mathrm{Mn}$, and $\mathrm{Cu}$ is not specified. When fed at the recommended amount, both products deliver similar amounts of $\mathrm{Zn}(360 \mathrm{mg})$, Mn (200 mg), and $\mathrm{Cu}(125 \mathrm{mg})$, but 4-Plex provides $25 \mathrm{mg}$ of Co, whereas Availa-4 provides $12 \mathrm{mg}$ of Co. There are reports that these OTM are biologically more available than inorganic forms of the minerals and can improve health and productivity of dairy cows (Uchida et al., 2001; Yost et al., 2002; DeFrain et al., 2009).

Meta-analysis is a statistical review technique that provides greater statistical power in quantifying the overall production response than do individual experimental studies by substantially increasing the sample population size. The objectives of this meta-analysis 
Table 1. Study qualities (factors), such as form of publication, randomization, and if the outcomes of studies were adjusted for potential, were used to evaluate the outcome of the study

\begin{tabular}{|c|c|c|c|c|c|c|}
\hline \multirow[b]{2}{*}{ Study quality } & \multicolumn{2}{|c|}{ Peer reviewed, \% (n) } & \multicolumn{2}{|c|}{ Randomized, \% (n) } & \multicolumn{2}{|c|}{ Confounder, \% (n) } \\
\hline & Yes & No & Yes & No & Yes & No \\
\hline \multicolumn{7}{|l|}{ Source of paper } \\
\hline Journal and thesis & $100(12 / 12)$ & $0.0(0 / 12)$ & $100(12 / 12)$ & $0.0(0 / 12)$ & $91.7(11 / 12)$ & $8.3(1 / 12)$ \\
\hline Technical bulletins, abstracts, reports & $0.0(0 / 12)$ & $100(12 / 12)$ & $33.3(4 / 12)$ & $66.7(8 / 12)$ & $8.3(1 / 12)$ & $91.7(12 / 12)$ \\
\hline \multicolumn{7}{|l|}{ Peer reviewed } \\
\hline Yes & & & $100(12 / 12)$ & $0.0(1 / 12)$ & $84.6(11 / 13)$ & $15.4(2 / 13)$ \\
\hline Yes & & & & & $70.6(12 / 16)$ & $29.4(4 / 16)$ \\
\hline No & & & & & $0.0(0 / 8)$ & $100(8 / 8)$ \\
\hline
\end{tabular}

were to critically review randomized controlled trials that evaluate the effectiveness of supplementation with 2 OTM products (Availa-4 and 4-Plex, Zinpro Corp.) on productivity, reproductive performance, and foot health, and to explore sources of heterogeneity between studies and evaluate the potential for publication bias.

\section{MATERIALS AND METHODS}

Published and unpublished studies and reports of OTM studies were collated and critically reviewed to quantify the effects of Availa-4 and 4-Plex on dairy cattle production, reproduction, and claw integrity.

\section{Literature Search}

A total of 22 research papers and reports (Table 1) were provided by Zinpro Corporation to be considered in this meta-analysis. The first 2 authors also conducted an independent literature search (PubMed, Google Scholar, CAB, ISI Web of Knowledge, Science Direct, SciQuest, and Scirus) to explore and identify other research papers and reports that may not have been provided by Zinpro. Our literature search did not find any papers other than those provided by Zinpro. Randomized clinical trials that examined the effects of Availa-4 and 4-Plex on production measures, reproductive performance, and claw integrity in lactating dairy cows were considered for this study. Publications that were used in this study were technical bulletins $(\mathrm{n}=8)$, reports $(n=2)$, theses $(n=2)$, published abstracts and technical bulletins published as abstracts $(n=4)$, journals $(\mathrm{n}=10)$, and translations from other languages $(\mathrm{n}=1)$. Some of these studies may have been initially published as reports or technical bulletins and later published in abstracts, proceedings, or peer-reviewed journals. If the results of a study were published as different publications, these were cross-checked and results were used only once. There was no duplication of data used in the analyses. The published and peer-reviewed version of each study was used if available.

\section{Assessment of Quality of Papers}

The quality of the papers and reports was assessed using quality assessment criteria developed by the first 2 authors of this study. Criteria examined included randomization of study groups, blinding in treatment application, recording of production outcomes, statistical analysis, and comparability of treatment groups at entry to each trial.

Table 1 shows the number and percentage of peerreviewed studies that were published in scientific journals and whether randomization was documented in the study designs. Studies that were published or reported as technical bulletins or reports were considered as nonpeer-reviewed studies. The non-peer-reviewed studies were assessed and included in the meta-analysis if they met the selection criteria. Initially, 5 studies failed to document and report randomization; however, based on additional information provided by Zinpro Corporation, the studies were included.

\section{Inclusion and Exclusion Criteria}

Studies were included in the study if they reported the following: the form of OTM (Availa-4 or 4-Plex), an adequate description of randomization procedures used, number of animals in each group, whether the animals were lactating dairy cows, sufficient data to determine the effect size for production outcomes or risk of reproductive outcomes, a measure of effect amendable to calculation of a standardized mean difference (SMD) for continuous data or risk ratio (RR) for rate data, and a measure of variance (SE or SD) or $P$-value for each effect estimate or treatment and control comparisons. The following data were extracted from the studies when the information was present; the form of OTM (Availa-4 or 4-Plex), duration of supplementation during precalving and postcalving periods, use of other supplements, delivery method of OTM, parity of cows used, and estrus synchrony program, if used. The study of Nocek et al. (2000) failed to meet the essential 
criteria for the randomized controlled trial and was consequently excluded. That of McKay et al. (2002) was excluded from the meta-analysis because of an error in concentrate formulation by the feed manufacturer that led to ruminal acidosis and high mortality rates of cows in the Availa-4 group. Therefore, a total of 20 studies met the eligibility criteria for meta-analysis.

\section{Data Extraction}

Data recorded from the studies included milk production and composition (fat and protein percentages), milk SCC, 3.5\% FCM, ECM, milk solids yield, and reproductive data including days to first service (DFS), days open (DO), services per conception, 21-d pregnancy rate, and risk of pregnancy by $150 \mathrm{~d}$ of lactation.

The extracted data also included number of cows in control and treatment groups, measures of variance of responses (SE or SD), and $P$-values. Other information extracted from relevant papers included the duration of treatment before and after calving, stage of lactation, and types of diets. A summary of studies and variables measured is presented in Table 2. One study (Kellogg et al., 2003) contained 4 comparisons that included 2 controls (base and sulfate minerals) compared with Availa-4 and 4-Plex. The study of Nocek et al. (2006) was also split over years. Details of mineral supplementations in control and treatment groups are provided in Table 2.

\section{Statistical Analysis}

A meta-analysis was conducted on the extracted production outcomes using Stata (Intercooled Stata v.11, StataCorp, College Station, TX).

Continuous Data. Continuous data were analyzed using SMD, which is also called effect size, in which the difference between treatment and control groups means was standardized using the standard deviations of control and treatment groups. The SMD estimates were pooled using the methods of Cohen (1988) for the fixed effects model and DerSimonian and Laird (1986) for the random effects models. If the paper reported separate estimates of measure of variance (SE or SD) for each group, these were recorded as such. If the studies reported a common SE or SD, the estimate was used for both control and treatment groups. If the study only reported a $\mathrm{Z}$ statistic or $P$-value, estimates of SE or SD were computed using the number of cows in each group. For studies that only reported a $P$-value less than or equal to a given value (e.g., $P<$ or $>$ 0.05 ), then the given value was used and $P$-value and SE were computed similar to the methods described above. For studies that only reported a nonsignificant effect, $P$-values of $0.15,0.3$, and 0.5 were assigned and compared as described by Sanchez et al. (2004). The $P$-value that produced the smallest estimate of overall SMD was selected for the calculation of the standard error. Fixed and random effects models were conducted for each production outcome to estimate the effect size, 95\% CI, and statistical significance of SMD.

Rate Data. Rate data were analyzed using RR and pooled with both fixed (Mantel and Haenszel, 1959) and random effects (DerSimonian and Laird, 1986) models. The random effects model only was presented. Because of the limited number of studies reporting the incidence of claw lesions, claw lesion results are not presented in this paper.

Assessment of Heterogeneity. Variations among the trial level SMD or RR were assessed using a chisquared $(\mathbf{Q})$ test of heterogeneity. We used an $\alpha$ level of 0.10 because of the relatively poor power of the $\chi^{2}$ test to detect heterogeneity among small numbers of trials (Egger and Smith, 2001). Heterogeneity of results among the trials was quantified using the $I^{2}$ statistic (Higgins and Thompson, 2002; Higgins et al., 2003). Negative values of $I^{2}$ were assigned a value of zero; consequently, $I^{2}$ lies between 0 and $100 \%$. An $I^{2}$ value $>50 \%$ may be considered indicative of substantial heterogeneity.

Meta-Regression. Meta-regression is a technique that can formally test whether there is evidence of different effects in different subgroups of trials. It examines the relationship between one or more study-level characteristics and the SMD observed in the studies. Meta-regression extends a random effects meta-analysis to estimate the extent to which one or more covariates, with values defined for each study in the analysis, explain heterogeneity in treatment effects. Meta-regression fits models with 2 additive components of variance, one representing the variance within units and the other representing the variance between units. A random effect meta-regression is used in this study consistent with modifications of Knapp and Hartung (2003) methods. The Knapp-Hartung variance estimator results by calculating a quadratic form, $q$, and multiplying the usual variance estimates by $q$ if $q>1$. This estimator was used with a $t$ distribution when calculating $P$-values and confidence intervals. The modified Knapp-Hartung test (Harbord and Higgins, 2008) was used to estimate the probability of meta-regression using the joint test for all covariates in the model.

Study Quality. To examine whether aspects of study design or source of publications influenced the outcome of studies, a meta-regression was conducted adjusting for the effect of type of paper (journal vs. abstract, technical bulletins, and reports), whether or not the 
$\stackrel{\complement}{\subseteq}$ Table 2. Summary of studies with Availa-4 and 4-Plex (organic trace minerals, OTM) during pre- and postcalving periods in primiparous and multiparous cows on different diets and with various breeding programs

\begin{tabular}{|c|c|c|c|c|c|c|c|c|c|c|}
\hline \multirow[b]{2}{*}{ Study } & \multicolumn{2}{|c|}{$\begin{array}{l}\text { Duration of OTM } \\
\text { supplementation }\end{array}$} & \multicolumn{5}{|c|}{ Diets, parity, and supplements } & \multicolumn{3}{|c|}{ Breeding program } \\
\hline & $\begin{array}{l}\text { Precalving } \\
\text { (d) }\end{array}$ & $\begin{array}{l}\text { Postcalving } \\
\text { (d) }\end{array}$ & Diet & Parity $^{1}$ & $\begin{array}{l}\text { Zinpro } \\
\text { product }^{2}\end{array}$ & $\begin{array}{l}\mathrm{bST} \\
(\text { yes } / \text { no })\end{array}$ & $\begin{array}{l}\text { Other } \\
\text { supplements }\end{array}$ & Calving & $\begin{array}{l}\text { Synchrony } \\
\text { program }\end{array}$ & $\begin{array}{l}\text { Hormones } \\
\text { used }^{3}\end{array}$ \\
\hline Campbell et al. (1999) & 0 & 154; early-mid & $\begin{array}{l}\text { TMR }+ \\
10 \mathrm{~kg} \text { grain }\end{array}$ & M & 4-Plex & Yes & None & $\mathrm{AYR}^{4}$ & No & None \\
\hline $\begin{array}{l}\text { Kellogg et al. }(2003) \\
\text { (Texas study 1) }\end{array}$ & 0 & 100; early-mid & TMR & $\mathrm{M}$ & 4-Plex & Yes & None & AYR & No & None \\
\hline $\begin{array}{l}\text { Kellogg et al. }(2003) \\
\text { (Texas study } 2 \text { ) }\end{array}$ & 0 & 348; early-mid-late & TMR & $\mathrm{P} / \mathrm{M}$ & 4-Plex & Yes & None & AYR & No & None \\
\hline Kellogg et al. (2003) (NY study 1) & 50 & 365; early-mid-late & TMR & $\mathrm{P} / \mathrm{M}$ & 4-Plex & No & None & AYR & No & $\mathrm{PGF}_{2 \alpha}$ \\
\hline $\begin{array}{l}\text { Kellogg et al. (2003) } \\
\text { (Colorado study) }\end{array}$ & 0 & 365 ; early-mid-late & TMR & $\mathrm{M}$ & 4-Plex & No & None & AYR & No & None \\
\hline $\begin{array}{l}\text { Kellogg et al. (2003) } \\
\text { (Mexico, Bravo Thesis, 1997) }\end{array}$ & 0 & 240; early-mid-late & TMR & $\mathrm{P} / \mathrm{M}$ & 4-Plex & No & Monensin & AYR & No & None \\
\hline $\begin{array}{l}\text { Kellogg et al. (2003) } \\
\text { (California study) }\end{array}$ & 21 & 160; early-mid & TMR & $\mathrm{P} / \mathrm{M}$ & & Yes & Monensin & AYR & No & $\mathrm{PGF}_{2 \alpha}$ \\
\hline Control vs. 4-Plex & & & & & 4-Plex & & & & & \\
\hline Sulfates vs. 4-Plex & & & & & 4-Plex & & & & & \\
\hline Control vs. Availa-4 & & & & & Availa-4 & & & & & \\
\hline $\begin{array}{l}\text { Sulfates vs. Availa-4 } \\
\text { Kellogg et al. }(2003) \\
\text { [Sneed et al. }(2001)]\end{array}$ & 21 & 150; early-mid & TMR & $\mathrm{P} / \mathrm{M}$ & $\begin{array}{l}\text { Availa-4 } \\
\text { 4-Plex }\end{array}$ & Yes & None & Batch & No & $\mathrm{PGF}_{2 \alpha}$ \\
\hline Uchida et al. (2001) & 0 & 80; early & TMR & $\mathrm{P} / \mathrm{M}$ & Availa-4 & Yes & None & AYR & No & $\mathrm{PGF}_{2 \alpha}$ \\
\hline Griffiths et al. (2007) & 35 & 230; early-mid-late & Pasture & $\mathrm{P} / \mathrm{M}$ & Availa-4 & No & Bloat oil & Seasonal & No & $\mathrm{CIDR}+\mathrm{E}_{2}$ \\
\hline Ballantine et al. (2002) & 21 & 250; early-mid-late & TMR & $\mathrm{M}$ & Availa-4 & Yes & Monensin & Batch & No & $\mathrm{PGF}_{2 \alpha}$ \\
\hline Kincaid and Socha (2007) & 21 & 150; early-mid & TMR & M & 4-Plex & No & None & AYR & No & $\mathrm{PGF}_{2 \alpha}$ \\
\hline Ferguson et al. (2004) & 60 & 250; early-mid-late & TMR & $\mathrm{P} / \mathrm{M}$ & 4 -Plex & Yes & None & AYR & $\begin{array}{l}\text { Yes; } \\
\text { Presynch }\end{array}$ & $\mathrm{PGF}_{2 \alpha}+\mathrm{GnRH}$ \\
\hline Monardes et al. (2002) & 0 & 60 ; early & TMR & $\mathrm{M}$ & 4-Plex & No & None & AYR & & $\mathrm{PGF}_{2 \alpha}$ \\
\hline Nocek et al. (2006); year 1 & 60 & 150; early-mid-late & TMR & $\mathrm{P} / \mathrm{M}$ & 4-Plex & No & Yeast and & AYR & Yes; Ovsyncl & $\mathrm{PGFF}_{2 \alpha}+\mathrm{GnRH}$ \\
\hline $\begin{array}{l}\text { Nocek et al. (2006); year } 2 \\
\text { Toni et al. }(2007)\end{array}$ & $\begin{array}{l}42 \\
60\end{array}$ & $\begin{array}{l}\text { 200; early-mid-late } \\
\text { 200; early-mid-late }\end{array}$ & Component $^{5}$ & & Araila-4 & $\mathrm{No}$ & mycotoxin binder & $A Y B$ & 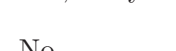 & $\cos 2 \cos 20$ \\
\hline Lean et al. (2004) & 21 & 250; early-mid-late & $\mathrm{PMR}^{6}$ & $\mathrm{P} / \mathrm{M}$ & Availa-4 & No & $\begin{array}{l}\text { Monensin, Tylan } \\
\text { (Biochlor fed during } \\
\text { transition period) }\end{array}$ & Batch & $\begin{array}{l}\text { Yes; double } \\
\text { PG }\end{array}$ & $2 \times \mathrm{PGF}_{2 \alpha}$ \\
\hline McKay et al. (2002) & 21 & 225; early-mid-late & Pasture & $\mathrm{P} / \mathrm{M}$ & Availa-4 & No & $\begin{array}{l}\text { Bloat oil, } \mathrm{ZnO} \\
\text { during } \mathrm{FE}^{7} \text { season }\end{array}$ & Seasonal & No & None \\
\hline Siciliano-Jones et al. (2008) & 21 & 250; early-mid-late & $\mathrm{TMR}+15$ & $\mathrm{P} / \mathrm{M}$ & Availa-4 & Yes & $\begin{array}{l}\text { Yeast, mycotoxin } \\
\text { binder (monensin } \\
\text { fed precalving) }\end{array}$ & AYR & Yes; Ovsyncl & $\mathrm{hPGF}_{2 \alpha}+\mathrm{GnRH}$ \\
\hline DeFrain et al. (2009) & 21 & 250; early-mid-late & TMR & $\mathrm{M}$ & 4-Plex & Yes & Biotin, monensin & AYR & Ovsynch & $\mathrm{GnRH}+\mathrm{CIDR}$ \\
\hline Hackbart (2008) & 56 & 98 ; early & TMR & $\mathrm{P} / \mathrm{M}$ & 4-Plex & No & Monensin & AYR & Ovsynch & $\mathrm{GnRH}+\mathrm{CIDR}$ \\
\hline
\end{tabular}

${ }^{1} \mathrm{M}=$ multiparous, $\mathrm{P}=$ primiparous

${ }^{2}$ Availa-4 and 4-Plex from Zinpro Corp. (Eden Prairie, MN).

${ }^{3} \mathrm{CIDR}=$ controlled internal drug releasing device; $\mathrm{E}_{2}=$ estradiol

${ }^{4} \mathrm{AYR}=$ all year round calving.

${ }^{5}$ Component $=$ forages fed separately from concentrate.

${ }^{6} \mathrm{PMR}=$ partial mixed ration.

${ }^{7} \mathrm{FE}=$ facial eczema 
paper was peer-reviewed, and presence or absence of a formal randomization process described in the materials and methods. These outcomes were often closely related (Table 3 ). If these were closely related, only one of the above factors was used in the meta-regression.

Meta-regression analyses were used to explore the source of heterogeneity of response, using the individual SMD for each trial as the outcome and the associated standard error as the measure of variance. A meta-regression was conducted to explore whether the outcomes were influenced by duration of treatment before calving, duration of treatment after calving (DIM), mating pattern (year round vs. seasonal and batch calving) category, number of milkings per day (2 vs. 3), parity of cows in the study (multiparous vs. multiparous and primiparous), bST treatment, type of OTM administered (Availa-4 vs. 4-Plex), delivery method (mixed with diet vs. drinking water and gel bolus), and presence or absence of other supplements in the diet (no supplement vs. monensin and others).

Meta-regression analysis was conducted by first screening individual variables using a $P$-value of $\leq 0.20$. All variables with $P$-value of $\leq 0.20$ were entered into a backward stepwise weighted meta-regression, until all remaining variables were significant at $P<0.05$. For the rate data, meta-regression was conducted on the logged RR and their standard errors.

Publication Bias. The presence of publication bias was investigated using contour-enhanced funnel plots. Contour-enhanced funnel plots have been proposed by Peters et al. (2008) to include contour lines corresponding to the statistical significance $(P=0.01,0.05,0.1)$. This approach allows the statistical significance of study estimates and areas in which studies are perceived to be missing, to be considered. Funnel plots were not constructed for the data sets comprising fewer than 7 studies.

Influence Analysis. Influence analysis (Tobias, 1999) was conducted to investigate the influence of each individual study on the overall meta-analysis summary estimate. With this method, the pooled estimates were recalculated after omitting one study at a time. The influence graph provides the results in a plot, naming the omitted study on the left margin and presenting the resulting "omitted" meta-analytic summary statistics as a horizontal confidence interval. The full, combined results are shown as the solid vertical lines.

\section{RESULTS}

Several studies, reports, or technical bulletins failed to provide production data with a measure of variance and level of significance. Some of these data were subsequently provided after the authors of the studies in

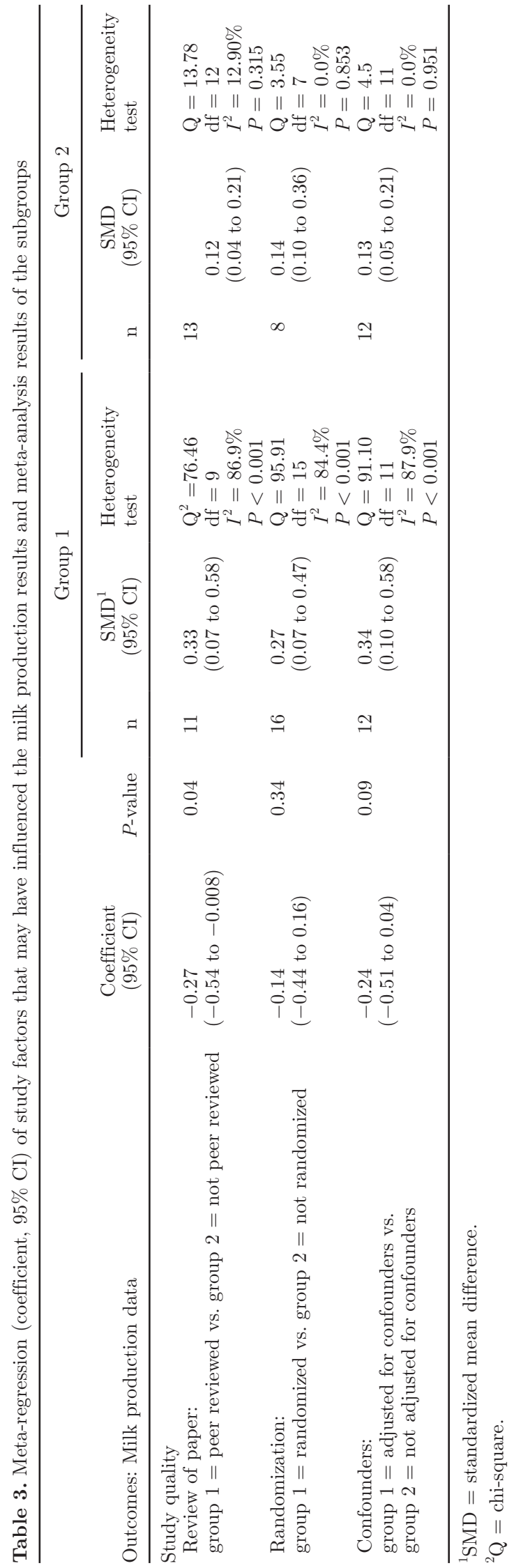

Journal of Dairy Science Vol. 93 No. 9, 2010 
question were contacted. All papers and reports were critically reviewed and study information was extracted and summarized as shown in Table 2. All studies, except the one that did not meet the criteria for acceptance, were used in the analysis despite concerns about the quality of studies that were not reported in peer-reviewed papers. The reproduction results from Hackbart (2008) were excluded from the analysis because cows were superovulated and then flushed for the collection of embryos on several occasions before the breeding program.

Percentages of papers published in different formats (e.g., peer-reviewed vs. abstract), information on randomization, and control for potential confounders for milk production are summarized in Table 2 . The subgroup and meta-regression analyses showed that the SMD of milk production of the peer-reviewed studies $(\mathrm{SMD}=0.33)$ was greater than those published as abstracts or technical reports $(\mathrm{SMD}=0.13 ; P=0.04)$. The SMD of studies with appropriate randomization, which controlled the outcome for potential confounders, were greater than in those studies that did not allocate animals randomly and reported unadjusted results (Table 3 ).

\section{Milk Production}

Tables 4 and 5 provide a summary of 20 studies containing 25 comparisons with Availa-4 ( $\mathrm{n}=8$ trials) and 4 -Plex ( $\mathrm{n}=16$ trials) with production results. The meta-regression results for sources of heterogeneity are provided in Table 6. Organic trace minerals increased milk production $(\mathrm{SMD}=0.23,95 \%$ CI: 0.10 to $0.36 ; P$ $=0.001$, Figure 1$), \mathrm{ECM}(\mathrm{SMD}=0.16,95 \%$ CI: 0.10 to $0.22 ; P<0.001$ ), and $3.5 \% \mathrm{FCM}(\mathrm{SMD}=0.18,95 \%$ CI: 0.12 to $0.24 ; P<0.001$ ), but these data were highly heterogeneous (Tables 4 and 5). The influence analysis of milk production results showed that the study of Nocek et al. (2006) was influential. The sensitivity analysis conducted after removing the Nocek et al. (2006) study showed that the SMD of milk production was 0.14 (95\% CI: 0.08 to 0.20$)$ and the results were homogeneous $\left(I^{2}=1.3 \% ; P=0.44\right)$. Meta-regression analysis showed that the use of other forms of supplements, type of OTM, and duration of treatment before and after calving were the sources of heterogeneity for milk production and ECM (Table 6). However, following exclusion of the Nocek et al. (2006) study, there was little difference between the SMD of Availa-4 (0.138) and 4-Plex (0.141). There was also some evidence of publication bias in production outcomes. Small studies that reported a reduction in milk production (Figure 2) and ECM were more likely to be published than small studies with an increase in milk production. Influence analysis showed that the study of Nocek et al. (2006) was influential in reporting a positive effect of OTM on production outcomes.

\section{Milk Fat and Protein Yields}

The SMD for milk fat and protein (\% and yield) and milk solids (yield) are presented in Table 4. The OTM increased milk fat yield (SMD $=0.18,95 \%$ CI: 0.12 to $0.23 ; P<0.001)$, milk protein yield $(\mathrm{SMD}=0.16$, 95\% CI: 0.10 to $0.21 ; P<0.001$ ), and milk solids yield $(\mathrm{SMD}=0.11,95 \%$ CI: 0.05 to $0.17 ; P<0.001)$. Milk fat and protein yield data were highly heterogeneous (Table 5). Meta-regression analysis showed that the use of other supplements and duration of treatment before calving influenced milk fat and protein yields, respectively (Table 6). Funnel plots (figures not provided here) indicated the presence of publication bias, in which small studies that reported a reduction for these outcomes, except milk solids, were less likely to be published. Results for milk solids yield were homogeneous $(P=0.45$, Table 5$)$.

\section{Milk Fat and Protein Percentage and Milk SCC}

Milk fat and protein percentages were not significantly influenced by supplementation with OTM (Table $5)$. The milk fat and protein percentage responses to treatment were highly heterogeneous (Table 6), and meta-regression analysis showed that the duration of treatment before and after calving was the source of heterogeneity of milk protein percentage (Table 6). The funnel plots also showed some evidence of publication bias. The effect of OTM on average milk SCC is presented in Table 5. The estimated SMD for milk lnSCC was -0.02 (95\% CI: -0.08 to $0.04 ; P=0.50)$, indicating a small, nonsignificant reduction in milk SCC. There was evidence of heterogeneity in milk SCC data, but meta-regression analysis did not identify sources of heterogeneity for the variables examined in this study. The funnel plots showed little or no evidence of publication bias in milk SCC data (Figure 3).

\section{Reproductive Outcomes}

A summary of effects of the organic trace minerals on reproduction is presented in Table 7 . The OTM decreased days open $(\mathrm{SMD}=-0.14,95 \% \mathrm{CI} ;-0.23$ to $-0.05 ; P=0.006)$. The weighted mean difference (WMD) was $13.5 \mathrm{~d}$ in DO in the treated group. There was no evidence of heterogeneity for the DO data $(P=$ 0.48 ; Table 7). Treatment had no significant effect on DFS (SMD $=-0.06,95 \%$ CI: -0.14 to $0.04 ; P=0.25$ ) or 21 -d pregnancy rates $(\mathrm{RR}=1.06,95 \% \mathrm{CI}: 0.90$ to 
Table 4. Standardized mean difference (SMD), significance, weighted mean difference (WMD), and heterogeneity of milk production in lactating dairy cows

\begin{tabular}{|c|c|c|c|c|c|c|c|c|}
\hline \multirow[b]{2}{*}{ Outcome $^{1}$} & \multirow[b]{2}{*}{$\mathrm{n}$} & \multicolumn{2}{|c|}{$\operatorname{SMD}(95 \%$ CI $)$} & \multicolumn{4}{|c|}{ Heterogeneity test } & \multirow[b]{2}{*}{$\begin{array}{l}\text { WMD }(\mathrm{kg} / \mathrm{d}) \\
(95 \% \mathrm{CI})\end{array}$} \\
\hline & & $\begin{array}{l}\text { Random } \\
\text { effect }\end{array}$ & $P$-value & $\begin{array}{c}\text { Chi-square } \\
\text { (Q) }\end{array}$ & df & $I^{2}(\%)$ & $P$-value & \\
\hline Milk yield $(\mathrm{kg} / \mathrm{d})$ All & 24 & $\begin{array}{l}0.23 \\
(0.10 \text { to } 0.36)\end{array}$ & 0.001 & 103.32 & 23 & 77.7 & $<0.001$ & $\begin{array}{l}0.93 \\
(0.61 \text { to } 1.25)\end{array}$ \\
\hline Availa-4 & 8 & $\begin{array}{l}0.13 \\
(0.04 \text { to } 0.23)\end{array}$ & 0.008 & 8.31 & 7 & 15.8 & 0.308 & $\begin{array}{l}0.62 \\
(0.18 \text { to } 1.07)\end{array}$ \\
\hline Start after calving & 7 & $\begin{array}{l}0.21 \\
(0.04 \text { to } 0.38)\end{array}$ & 0.001 & 10.73 & 6 & 44.1 & 0.097 & $\begin{array}{l}0.81 \\
(0.42 \text { to } 1.20)\end{array}$ \\
\hline Starts before calving & 17 & $\begin{array}{l}0.23 \\
(0.07 \text { to } 0.40)\end{array}$ & $<0.001$ & 92.38 & 16 & 82.7 & $<0.001$ & $\begin{array}{l}1.26 \\
(0.61 \text { to } 1.91)\end{array}$ \\
\hline Multiparous & 8 & $\begin{array}{l}0.17 \\
(0.05 \text { to } 0.29)\end{array}$ & 0.006 & 8.77 & 7 & 22.2 & 0.270 & $\begin{array}{l}1.01 \\
(0.28 \text { to } 1.74)\end{array}$ \\
\hline Primiparous/multiparous & 16 & $\begin{array}{l}0.26 \\
(0.08 \text { to } 0.44)\end{array}$ & 0.006 & 92.85 & 15 & 88.8 & $<0.001$ & $\begin{array}{l}0.90 \\
(0.52 \text { to } 1.29)\end{array}$ \\
\hline No other supplements & 11 & $\begin{array}{l}0.13 \\
(0.04 \text { to } 0.23)\end{array}$ & 0.005 & 5.71 & 10 & 0.0 & 0.839 & $\begin{array}{l}0.66 \\
(0.08 \text { to } 121)\end{array}$ \\
\hline Monensin and other supplements & 13 & $\begin{array}{l}0.32 \\
(0.10 \text { to } 0.36)\end{array}$ & 0.002 & 93.20 & 12 & 87.1 & $<0.001$ & $\begin{array}{l}0.99 \\
(0.53 \text { to } 1.45)\end{array}$ \\
\hline
\end{tabular}

${ }^{1}$ Availa-4 and 4-Plex from Zinpro Corp. (Eden Prairie, MN).

$1.23 ; P=0.42)$. Overall, the number of services per conception was lower in treated cows $(\mathrm{SMD}=-0.13,95 \%$ CI: -0.23 to $-0.02 ; P=0.02)$, and risk of pregnancy by d 150 of lactation was greater in cows fed OTM (RR $=1.07,95 \%$ CI: 0.99 to $1.16 ; P=0.07)$. A fixed effects model showed that risk of pregnancy on d 150 of lactation was greater in supplemented cows $(\mathrm{RR}=1.06$, 95\% CI: 1.01 to $1.21 ; P=0.03$; Figure 4 ). There was no evidence of heterogeneity in reproductive outcomes (Table 7); therefore, the fixed effect outcomes can be used for the interpretation of 150-d pregnancy data. There was also some evidence of publication bias in some of reproduction outcomes (figures not provided). Smaller studies that reported a reduction in DFS, DO, and number of services per conception were more likely to be published than small studies with an increase in these intervals and numbers (Figure 2). The funnel plot of 150-d pregnancy risk showed some evidence of publication bias, in which studies with greater risk of pregnancy on d 150 were more likely to be published.

Table 5. Standardized mean difference (SMD), significance, weighted mean difference (WMD), and heterogeneity of production outcomes

\begin{tabular}{|c|c|c|c|c|c|c|c|c|}
\hline Outcome & $\mathrm{n}$ & \multicolumn{2}{|c|}{ SMD $(95 \%$ CI $)$} & \multicolumn{4}{|c|}{ Heterogeneity } & $\begin{array}{c}\text { WMD }(\mathrm{kg} / \mathrm{d}) \\
(95 \% \mathrm{CI})\end{array}$ \\
\hline ECM $(\mathrm{kg} / \mathrm{d})$ & 22 & $\begin{array}{l}0.16 \\
(0.08 \text { to } 0.26)\end{array}$ & $<0.001$ & 43.71 & 21 & 52 & 0.003 & $\begin{array}{l}0.94 \\
(0.61 \text { to } 1.27)\end{array}$ \\
\hline $3.5 \%$ FCM $(\mathrm{kg} / \mathrm{d})$ & 22 & $\begin{array}{l}0.18 \\
(0.09 \text { to } 0.27)\end{array}$ & $<0.001$ & 41.24 & 21 & 49.1 & 0.005 & $\begin{array}{l}0.96 \\
(0.62 \text { to } 1.30)\end{array}$ \\
\hline Milk fat yield $(\mathrm{kg} / \mathrm{d})$ & 22 & $\begin{array}{l}0.18 \\
(0.08 \text { to } 0.28)\end{array}$ & $<0.001$ & 51.0 & 21 & 59.0 & $<0.001$ & $\begin{array}{l}0.04 \\
(0.02 \text { to } 0.05)\end{array}$ \\
\hline Milk solids (kg/d) & 22 & $\begin{array}{l}0.11 \\
(0.05 \text { to } 0.17)\end{array}$ & $<0.001$ & 19.5 & 21 & 0.00 & 0.45 & $\begin{array}{l}0.07 \\
(0.04 \text { to } 0.09)\end{array}$ \\
\hline Milk fat (\%) & 22 & $\begin{array}{l}-0.02 \\
(-0.11 \text { to } 0.06)\end{array}$ & 0.64 & 37.92 & 21 & 44.6 & 0.01 & $\begin{array}{l}0.009 \\
(-0.02 \text { to } 0.04)\end{array}$ \\
\hline Milk protein (\%) & 22 & $\begin{array}{c}0.02 \\
(-0.07 \text { to } 0.10)\end{array}$ & 0.71 & 36.77 & 21 & 42.9 & 0.02 & $\begin{array}{l}0.009 \\
(-0.007 \text { to } 0.02)\end{array}$ \\
\hline
\end{tabular}


Table 6. Meta-regression (coefficient and 95\% CI) of factors that may have influenced the production outcomes and meta-analysis of sub-groups

Table

Group 2

\begin{tabular}{|c|c|c|c|c|c|c|c|}
\hline Outcome $^{1}$ & $\begin{array}{l}\text { Coefficient } \\
(95 \% \mathrm{CI})\end{array}$ & $\begin{array}{l}\text { Test of } \\
\text { each } \\
\text { covariate }\end{array}$ & $\begin{array}{c}\text { Joint test } \\
\text { for all } \\
\text { covariates with } \\
\text { Knapp-Hartung } \\
\text { modification } \\
\text { test }\end{array}$ & $\begin{array}{c}\mathrm{n} \\
\mathrm{SMD}^{2} \\
(95 \% \mathrm{CI}) \\
\text { (random effects) } \\
P \text {-value }\end{array}$ & $\begin{array}{c}I^{2}(\%) \\
(P \text {-value })\end{array}$ & $\begin{array}{c}\mathrm{n} \\
\text { SMD } \\
(95 \% \mathrm{CI}) \\
\text { (random effects) } \\
P \text {-value }\end{array}$ & $\begin{array}{c}I^{2}(\%) \\
(P \text {-value })\end{array}$ \\
\hline \multicolumn{8}{|l|}{ Milk production (kg/d) } \\
\hline $\begin{array}{l}\text { Supplements } \\
\text { (group } 1=\text { none vs. group } 2=\text { monensin and others) }\end{array}$ & $\begin{array}{l}0.23 \\
(0.06 \text { to } 0.39)\end{array}$ & 0.01 & 0.02 & $\begin{array}{l}\mathrm{n}=11 \\
0.13 \\
(0.04 \text { to } 0.23) \\
0.005\end{array}$ & $\begin{array}{l}0.0 \\
(0.84)\end{array}$ & $\begin{array}{l}\mathrm{n}=13 \\
0.32 \\
(0.10 \text { to } 0.36)\end{array}$ & $\begin{array}{l}87.1 \\
(<0.001)\end{array}$ \\
\hline $\begin{array}{l}\text { Type of organic minerals } \\
\text { (group } 1=\text { Availa- } 4 \text { vs. group } 2=4 \text {-Plex) }\end{array}$ & $(-0.26$ to 0.12$)$ & 0.06 & & $\begin{array}{l}\mathrm{n}=8 \\
0.13 \\
(0.04 \text { to } 0.23)\end{array}$ & $\begin{array}{l}15.8 \\
(0.31)\end{array}$ & $\begin{array}{l}\mathrm{n}=16 \\
0.28 \\
(0.09 \text { to } 0.48)\end{array}$ & $\begin{array}{l}83.2 \\
(<0.001)\end{array}$ \\
\hline \multicolumn{8}{|l|}{ ECM $(\mathrm{kg} / \mathrm{d})$} \\
\hline $\begin{array}{l}\text { Duration of before calving } \\
\text { (group } 1=21-60 \mathrm{~d} \text { vs. group } 2=0 \mathrm{~d} \text { ) }\end{array}$ & $(-0.01$ to -0.004$)$ & 0.004 & 0.008 & $\begin{array}{l}\mathrm{n}=17 \\
0.19 \\
(0.09 \text { to } 0.30) \\
<0.001\end{array}$ & $\begin{array}{l}57.7 \\
(0.002)\end{array}$ & $\begin{array}{l}\mathrm{n}=7 \\
0.04 \\
(-0.08 \text { to } 0.16) \\
0.532\end{array}$ & $\begin{array}{l}0.0 \\
(0.83)\end{array}$ \\
\hline $\begin{array}{l}\text { Supplements } \\
\text { (group } 1=\text { none vs. group } 2=\text { monensin and others) }\end{array}$ & $\begin{array}{l}0.33 \\
(0.08 \text { to } 0.58)\end{array}$ & 0.01 & & $\begin{array}{l}\mathrm{n}=11 \\
0.05 \\
(-0.05 \text { to } 0.15) \\
0.283\end{array}$ & $\begin{array}{l}0.0 \\
(0.99)\end{array}$ & $\begin{array}{l}\mathrm{n}=13 \\
0.23 \\
(0.10 \text { to } 0.37) \\
<0.001\end{array}$ & $\begin{array}{l}68.8 \\
(<0.001)\end{array}$ \\
\hline $\begin{array}{l}3.5 \% \text { FCM }(\mathrm{kg} / \mathrm{d} \text { ) } \\
\text { Duration of before calving } \\
\text { (group } 1=21-60 \mathrm{~d} \text { vs. group } 2=0 \mathrm{~d} \text { ) }\end{array}$ & $(-0.004$ to 0.003$)$ & 0.065 & & $\begin{array}{l}\mathrm{n}=17 \\
0.19 \\
(-0.09 \text { to } 0.36) \\
<0.001\end{array}$ & $\begin{array}{l}57.4 \\
(0.02)\end{array}$ & $\begin{array}{l}\mathrm{n}=7 \\
0.12 \\
(-0.03 \text { to } 0.25) \\
0.06\end{array}$ & $\begin{array}{l}0.0 \\
(0.61)\end{array}$ \\
\hline $\begin{array}{l}\text { Milk fat yield }(\mathrm{kg} / \mathrm{d}) \\
\text { Supplements } \\
\text { (group } 1=\text { none vs. group } 2=\text { monensin and others) }\end{array}$ & $\begin{array}{l}0.20 \\
(-0.01 \text { to } 0.41)\end{array}$ & 0.065 & & $\begin{array}{l}\mathrm{n}=11 \\
0.05 \\
(-0.05 \text { to } 0.15) \\
0.325\end{array}$ & $\begin{array}{l}0.0 \\
(0.94)\end{array}$ & $\begin{array}{l}\mathrm{n}=13 \\
0.25 \\
(0.11 \text { to } 0.39) \\
<0.001\end{array}$ & $\begin{array}{l}71.3 \\
(<0.001)\end{array}$ \\
\hline $\begin{array}{l}\text { Milk protein yield }(\mathrm{kg} / \mathrm{d}) \\
\text { Duration of before calving feeding } \\
\text { (group } 1=21-60 \mathrm{~d} \text { vs. group } 2=0 \mathrm{~d} \text { ) }\end{array}$ & $(-0.004$ to 0.0004$)$ & 0.056 & & $\begin{array}{l}\mathrm{n}=17 \\
0.18 \\
(0.09 \text { to } 0.27) \\
<0.001\end{array}$ & $\begin{array}{l}57.4 \\
(0.002)\end{array}$ & $\begin{array}{l}\mathrm{n}=7 \\
0.12 \\
(-0.003 \text { to } 0.25) \\
0.007\end{array}$ & $\begin{array}{l}0.0 \\
(0.61)\end{array}$ \\
\hline $\begin{array}{l}\text { Milk fat }(\%) \\
\text { Duration of before calving feeding } \\
\text { (group } 1=21-60 \mathrm{~d} \text { vs. group } 2=0 \mathrm{~d} \text { ) }\end{array}$ & $\begin{array}{l}0.004 \\
(0.0003 \text { to } 0.008)\end{array}$ & 0.035 & 0.035 & $\begin{array}{l}\mathrm{n}=17 \\
0.19 \\
(0.09 \text { to } 0.30) \\
<0.001\end{array}$ & $\begin{array}{l}0.0 \\
(0.75)\end{array}$ & $\begin{array}{l}\mathrm{n}=7 \\
0.12 \\
(-0.003 \text { to } 0.25) \\
0.056\end{array}$ & $\begin{array}{l}61.4 \\
(<0.001)\end{array}$ \\
\hline
\end{tabular}




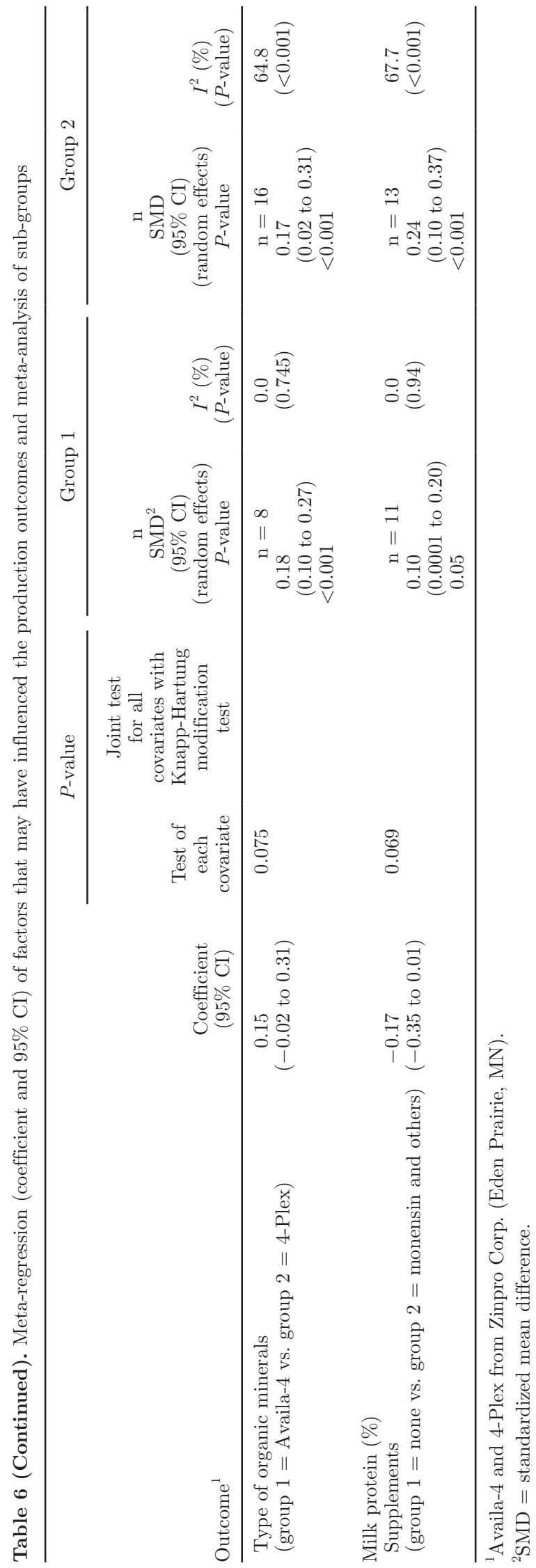

\section{DISCUSSION}

Although organic trace minerals are more available than inorganic sources, responses to supplementation have varied in individual trials. The objective of this study was to assess the responses of cattle on a larger population base and to identify sources of heterogeneity (i.e., variability) in responses. Studies used in this meta-analysis included papers not published in peerreviewed journals. Lean et al. (2009) concluded that it is desirable to obtain data from all relevant randomized trials, so that the most appropriate analysis can be undertaken. In this case, we examined the trials based on a priori established quality criteria, and noted that inclusion of these resulted in a more conservative point estimate and concluded that these should be included. We conducted sensitivity analysis on one trial that had an extremely positive milk production response (Nocek et al., 2006) and concluded that there was very little effect on point estimates or confidence intervals from inclusion or exclusion of that study.

Organic trace minerals significantly increased milk production by $0.93 \mathrm{~kg} / \mathrm{d}$, milk fat yield by $0.04 \mathrm{~kg} / \mathrm{d}$, and milk protein yield by $0.03 \mathrm{~kg} / \mathrm{d}$. Milk SCC was not significantly reduced by treatment, and milk fat and milk protein percentages were not significantly influenced by treatment. However, across all of the trials included in this study, production outcomes except milk solids ( $\mathrm{kg}$ and \%) and milk SCC were heterogeneous (Tables 4 and 5). This indicates that the response to supplementation with OTM is not uniformly consistent. Meta-regression analysis showed that milk production increased with the use of other supplements and for 4-Plex versus Availa-4. The results for use with other supplements or Availa-4 were still heterogeneous indicating residual variance (Table 6 ). Feeding OTM before calving, feeding for a full lactation after calving, and the use of other supplements (e.g., monensin) increased the responses to OTM for milk production outcomes including ECM and 3.5\% FCM. Milk production responses to OTM supplementation were higher in these subgroups of studies than for the entire population of studies. Funnel plots showed some evidence of publication bias for all milk production outcomes (e.g., Figure 2), indicating that small studies with no or less significant effects may not have been published. In most cases, the effect of this bias was thought to be minor. Given that the control diets varied considerably in composition and, specifically, in mineral content, some heterogeneity of responses should be anticipated.

The micronutrients $\mathrm{Cu}, \mathrm{Zn}$, and $\mathrm{Mn}$ are important components of enzyme systems involved in passive immune responses. Kellogg et al. (2003) found that feeding Zn Met improved milk production and reduced 


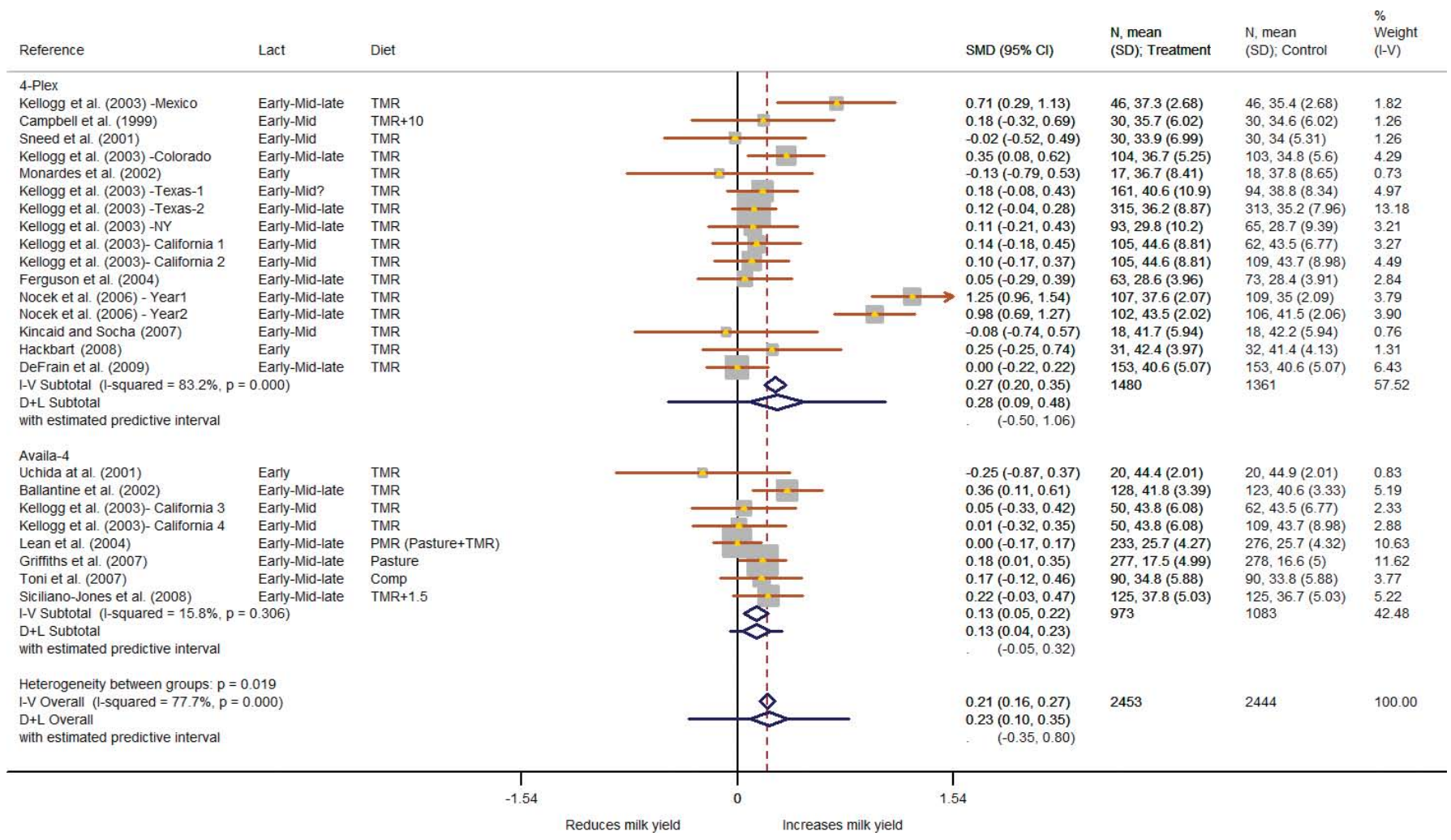

Figure 1. Forest plot of standardized mean difference (SMD) (and their 95\% CI and weights for individual trials) determined from the results of 24 trials comparing the milk production of cows supplemented with Availa-4 and 4-Plex (Zinpro Corp., Eden Prairie, MN) with other cows. Box sizes are proportional to the inverse variance of the estimates. Summary estimates of treatment effects are shown using 1) a fixed effects approach, 2) a random effects approach, and 3) the predicted interval of a future trial. I-V specifies a fixed effect model using the inverse variance method. $\mathrm{D}+\mathrm{L}$ specifies a random effects model using the method of DerSimonian and Laird (1986), with the estimate of heterogeneity being taken from the inverse variance fixed effect model. Color version available in the online PDF.

milk SCC in lactating dairy cows. In 4 of the 8 dairy trials, Zn Met significantly increased milk production (Aguilar and Jordan, 1990; Kellogg et al., 1989) and reduced SCC (Aguilar et al., 1988; Galton, 1990). Few published data are available on the effects of $\mathrm{Cu}$ on mastitis (Scaletti et al. 2003). There was a nonsignificant reduction in milk SCC in cows fed OTM in our meta-analysis, suggesting a need for more studies to fully explore differences between the Zn Met responses and those to the combined OTM. Many of the studies in

Table 7. Standardized mean difference (SMD), weighted mean difference (WMD), heterogeneity and level of significance of reproduction outcomes

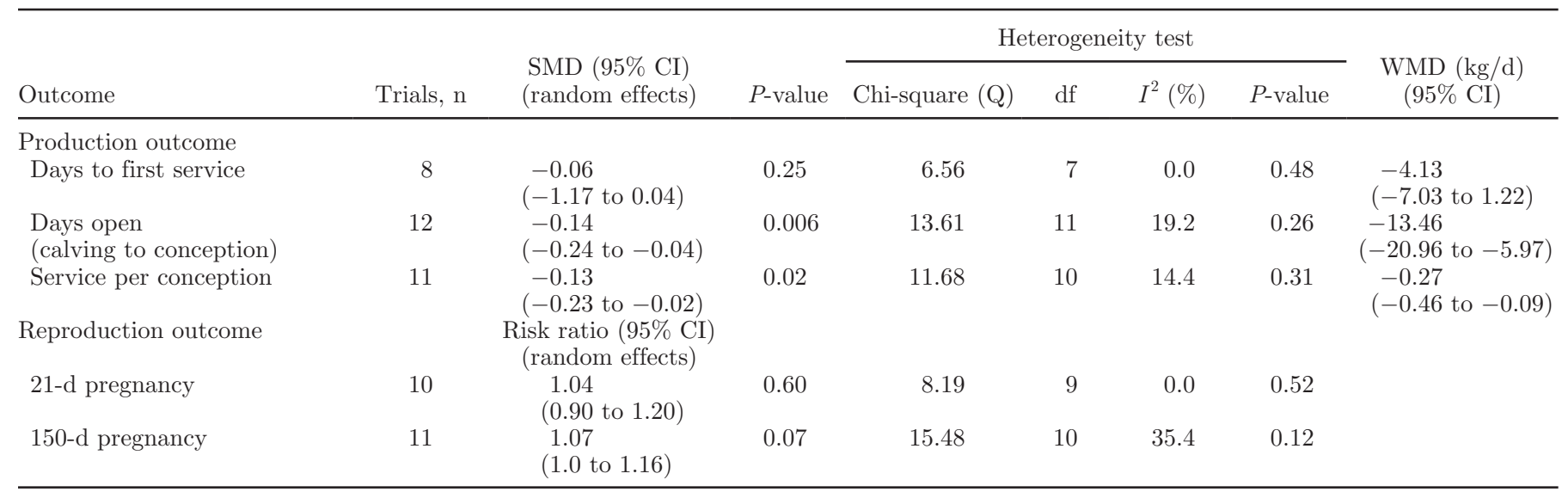




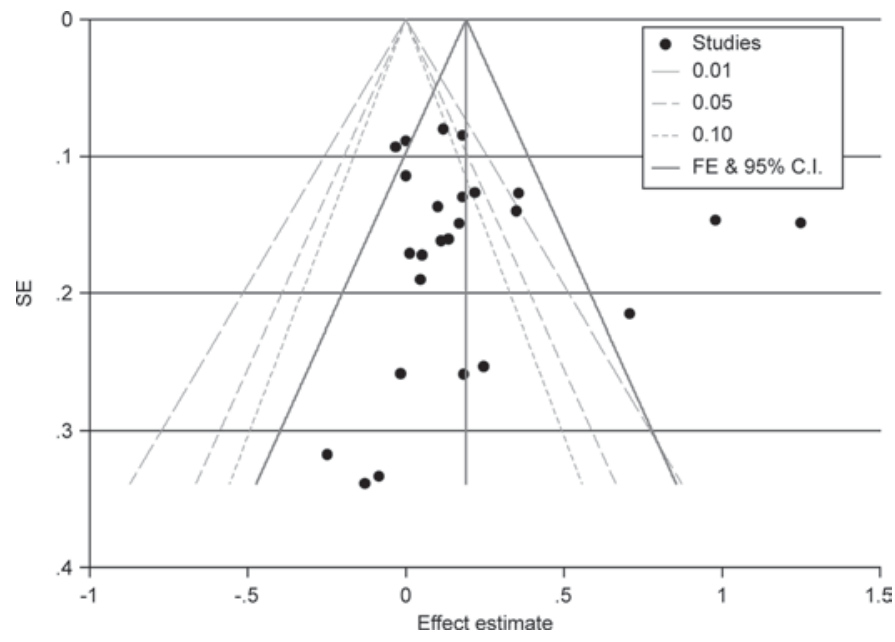

Figure 2. Contour-enhanced funnel plots of milk production data for cows supplemented with Availa-4 and 4-Plex (Zinpro Corp., Eden Prairie, MN). FE = fixed effect.

this meta-analysis had concentrations of trace elements in the diets of the control group consistent with NRC (2001) recommendations. In contrast, the $\mathrm{Zn}$ content of diets in the studies reviewed by Kellogg et al. (1989) was lower than that of diets in the trials reviewed in this study. It is also possible that the concentrations of trace elements in the control diets were sufficient to provide adequate concentrations of trace elements to reduce $\mathrm{SCC}$.

There are limited data supporting an effect of $\mathrm{Cu}$, $\mathrm{Zn}$, and Mn on the fertility of dairy cattle. The positive effects of $\mathrm{Cu}$ on fertility have largely been attributed to an effect of reducing the effects of excessive Mo intake (Phillippo et al., 1987). Studies of the effects of $\mathrm{Cu}$ and thiomolybdates on bovine theca cells in vitro provide support that negative effects on reproduction are more attributable to thiomolybdates than $\mathrm{Cu}$ (Kendall et al., 2006). There are some individual studies on the effects of OTM on reproductive performance of dairy cows. Uchida et al. (2001) found a shorter calving to conception interval in cows fed OTM in a small study, whereas Campbell et al. (1999) did not show a significant improvement in reproductive performance, apart from a positive effect on days to first estrus for cows supplemented with OTM.

Hansen et al. (2006) found that increasing supplemental $\mathrm{Mn}$ from 0 to $50 \mathrm{ppm}$ numerically increased heifers showing estrus after a prostaglandin injection from 40 to $50 \%$, first-service conception rates from 45 to $60 \%$, and overall pregnancy rate from 60 to $75 \%$. The lack of significant responses to treatment despite sizable improvements in these measures may reflect the small number of cattle used in the study.
The significant improvement in the fertility measures studied for cows supplemented with the OTM was consistent across studies. Days open was reduced by 13.5 d (Table 7) in OTM-treated cows, supplemented cows required fewer inseminations to become pregnant than did control cows $(P=0.01)$, and risk of pregnancy at $150 \mathrm{~d}$ of lactation was greater in cows fed OTM ( $P$ $=0.07$ ). There was no evidence of heterogeneity for reproductive outcomes. The improvements in reproduction suggest a positive role for OTM in reproductive management.

The finding of more positive effects for herds supplemented with other products (in most cases monensin; Table 2) was consistent for many of the variables studied. Sodium monensin increases uptake of monovalent and divalent cations in several species. Copper status is improved by the administration of sodium monensin in cattle (Starnes et al., 1984; Stephenson et al., 1997) and sheep (Elsasser, 1984; Van Ryssen, 1991). Selenium (Costa et al., 1985) and Zn (Starnes et al., 1984; Costa et al., 1985) status in cattle are also improved by supplementation with monensin. Tylosin also increases uptake or apparent digestibility of several macro- and microminerals. Kirchgessner et al. (1994) demonstrated an increase in apparent digestibility of $\mathrm{Fe}, \mathrm{Zn}, \mathrm{Cu}, \mathrm{Mn}$, and Se of up to $5 \%$ in pigs supplemented with tylosin at 20 to $40 \mathrm{mg} / \mathrm{kg}$ of live weight.

The results of this meta-analysis showed that the inclusion of 4-Plex and Availa-4 in diets of lactating dairy cows could improve production, reproduction, and health. For production responses, there was a high degree of heterogeneity, and responses were better when these products were fed throughout the entire lactation and when other supplements were fed. There

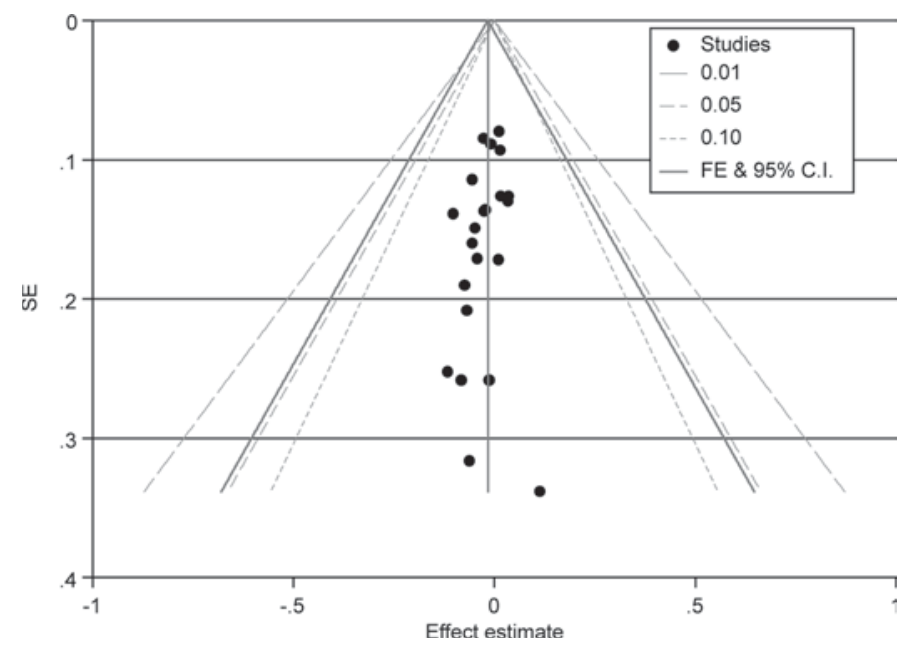

Figure 3. Contour-enhanced funnel plots of $\operatorname{lnSCC}$ data for cows supplemented with Availa-4 and 4-Plex (Zinpro Corp., Eden Prairie, $\mathrm{MN}) . \mathrm{FE}=$ fixed effect. 


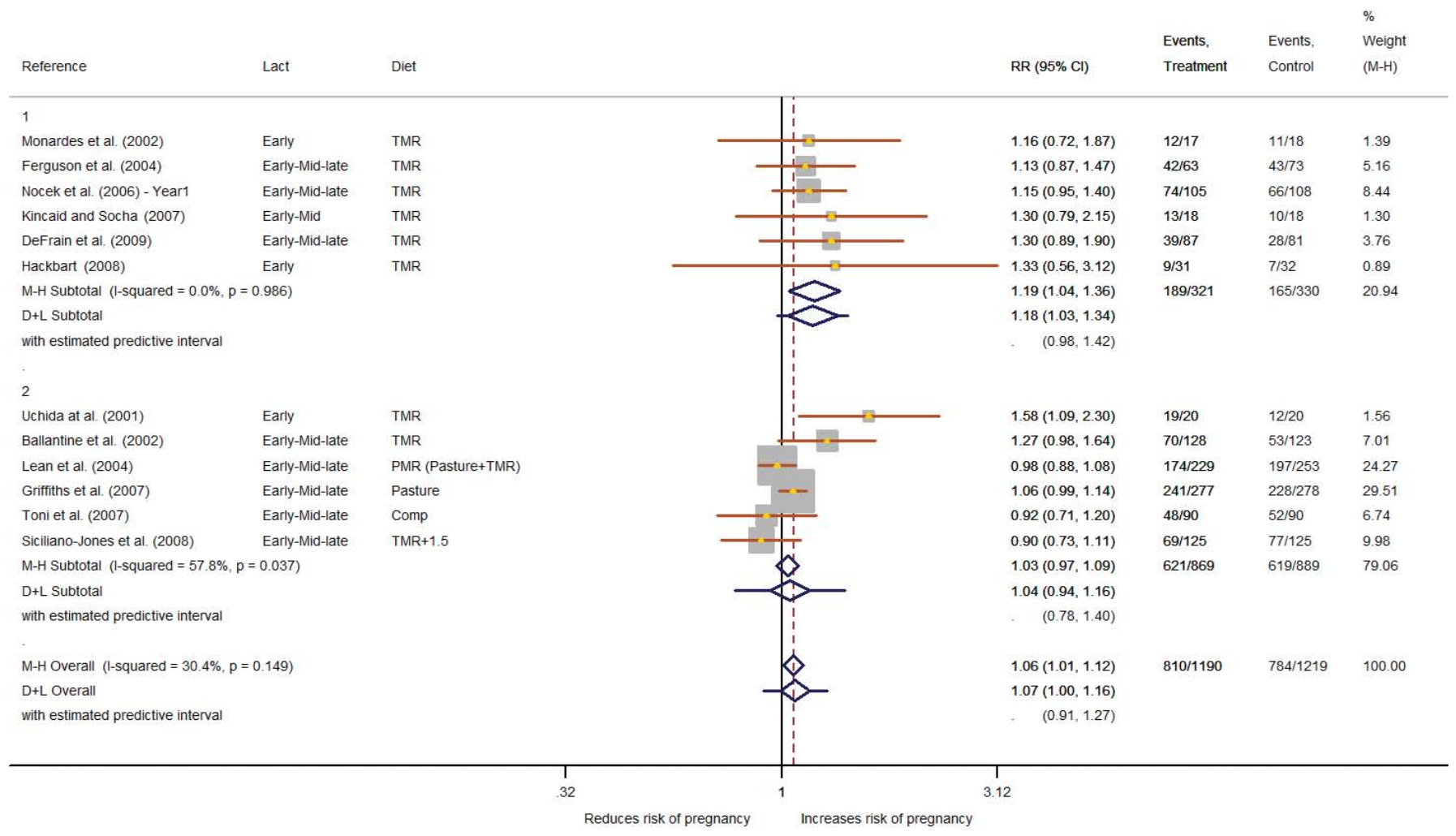

Figure 4. Forest plot of risk ratios (RR) (and their 95\% CI and weights for individual trials) determined from the results of 11 trials comparing the risk of pregnancy at day 150 of lactation in dairy cows supplemented with Availa-4 and 4-Plex (Zinpro Corp., Eden Prairie, MN). Box sizes are proportional to the inverse variance of the estimates. Summary estimates of treatment effects are shown using 1) a fixed effects approach, 2) a random effects approach, and 3) the predicted interval of a future trial. M-H specifies a fixed effect model using the method of Mantel and Haenszel (1959). D+L specifies a random effects model using the method of DerSimonian and Laird (1986), with the estimate of heterogeneity being taken from the Mantel and Haenszel fixed-effect model. Color version available in the online PDF.

was residual unexplained variation in the production responses, but less for reproductive responses, which were generally homogeneous. Given that the mineral background of control groups in studies varied, as did diets in general, heterogeneity of production responses was not surprising.

\section{REFERENCES}

Aguilar, A. A., and D. C. Jordan. 1990. Effects of zinc methionine supplementation in high producing Holstein cows early in lactation. Page 187 in Proc. 29th Annual Mtg., Louisville, KY. Natl. Mastitis Council, Arlington, VA.

Aguilar, A. A., M. Kujawa, and J. D. Olson. 1988. Zinc methionine supplementation in lactating dairy cows. Page 119 in Proc. 27th Annual Meeting National Mastitis Council, Reno, NV. Natl. Mastitis Council Inc., Arlington, VA.

Ballantine, H. T., M. T. Socha, D. J. Tomlinson, A. B. Johnson, A S. Fielding, J. K. Shearer, and S. R. Van Amstel. 2002. Effects of feeding complexed zinc, manganese, copper, and cobalt to late gestation and lactating dairy cows on claw integrity, reproduction, and lactation performance. Prof. Anim. Sci. 18:211-218.

Campbell, M. H., J. K. Miller, and F. N. Schrick. 1999. Effect of additional cobalt, copper, manganese and zinc on reproduction and milk yield of lactating dairy cows receiving bovine somatotropin. J. Dairy Sci. 82:1019-1025.
Cohen, J. 1988 Statistical Power Analysis for the Behavioral Sciences. 2nd ed. Academic Press, New York, NY.

Costa, N. D., P. T. Gleen, B. F. Sanson, H. W. Symonds, and W. M. Allen. 1985. Monensin and narasin increase selenium and zinc absorption in steers. Trace Element Metabolism in Man and Animals. C. F. Mills, I. Bremmer, and J. K. Chesters, ed. Commonwealth Agricultural Bureau, Slough, UK.

DeFrain, J. M., M. T. Socha, D. J. Tomlinson, and D. Kluth. 2009. Effect of complexed trace minerals on the performance of lactating dairy cows on a commercial dairy. Prof. Anim. Sci. 25:709-715.

DerSimonian, R., and N. Laird. 1986. Meta-analysis in clinical trials. Control. Clin. Trials 7:177-188.

Egger, M., and G. D. Smith. 2001. Principles of and procedures for systematic reviews. Pages 23-42 in Systematic Reviews in Health Care Meta-analysis in Context. M. Egger, G. D. Smith, and D. G. Altman, ed. British Medical Journal, London, UK.

Elsasser, T. H. 1984. Potential interactions of ionophore drugs with divalent cations and their function in the animal body. J. Anim. Sci. 59:845-853.

Ferguson, J. D., D. Tomlinson, and M. Socha. 2004. Effects of inorganic and organic (4-PlexR) trace mineral supplementation on milk production and reproduction. J. Dairy Sci. 87(Suppl. 1):117.

Galton, D. 1990. Effect of feeding Zinpro ${ }^{\circledR}$ to lactating dairy cows on udder health. Technical Bulletin \# D-8911. Zinpro Corp., Eden Prairie, MN.

Griffiths, L. M., S. H. Loeffler, M. T. Socha, D. J. Tomlinson, and A. B. Johnson. 2007. Effects of supplementing complexed zinc, manganese, copper and cobalt on lactation and reproductive performance of intensively grazed lactating dairy cattle on the 
South Island of New Zealand. Anim. Feed Sci. Technol. 137:69 83.

Hackbart, K. S. 2008. The effects of organic complexes of zinc, manganese, copper and cobalt on milk production, reproduction, and hepatic gene expression in dairy cows. MS Thesis. University of Wisconsin-Madison.

Hansen, S. L., J. W. Spears, K. E. Lloyd, and C. S. Whisnant. 2006. Growth, reproductive performance, and manganese status of heifers fed varying concentrations of manganese. J. Anim. Sci. 84:3375-3380.

Harbord, R. M., and P. T. Higgins. 2008. Meta-regression in Stata. Stata J. 8:493-519. http://www.stata-journal.com/article. html?article=sbe23_1.

Higgins, J. P. T., and S. G. Thompson. 2002. Quantifying heterogeneity in a meta-analysis. Stat. Med. 21:1539-1558.

Higgins, J. P. T., S. G. Thompson, J. J. Deeks, and D. G. Altman. 2003. Measuring inconsistency in meta-analysis. BMJ 327:557560.

Kellogg, D. W., J. M. Rakes, and D. W. Gliedt. 1989. Effects of zinc methionine supplementation on performance and selected blood parameters of lactating dairy cows. Nutr. Rep. Int. 40:10491057.

Kellogg, D. W, M. T. Socha, D. J. Tomlinson, and A. B. Johnson. 2003. Review: Effects of feeding cobalt glucoheptonate and metal specific amino acid complexes of zinc, manganese and copper on lactation and reproductive performance of dairy cows. Prof. Anim. Sci. 19:1-9.

Kendall, N. R., P. Marsters, L. Guo, R. J. Scaramuzzi, and B. K. Campbell. 2006. Effect of copper and thiomolybdates on bovine theca cell differentiation in vitro. J. Endocrinol. 189:455-463.

Kincaid, R. L., and M. T. Socha. 2007. Effect of cobalt supplementation during late gestation and early lactation on milk and serum measures. J. Dairy Sci. 90:1880-1886.

Kirchgessner, M., W. Windisch, and F. X. Roth. 1994. Effect of avilamycin and tylosin on apparent digestibilities of iron, zinc, copper, manganese and selenium in growing and finishing pigs. Arch. Anim. Nutr. 46:321-325.

Knapp, G., and J. Hartung. 2003. Improved tests for a random-effects meta-regression with a single covariate. Stat. Med. 22:26932710.

Lean, I. J., A. R. Rabiee, and P. J. DeGaris. 2004. The effects of Availa-4 on reproductive performance, milk production and locomotion and hoof scores of lactating dairy cows. Report to Zinpro Corporation, New Zealand.

Lean, I. J., A. R. Rabiee, T. F. Duffield, and I. R. Dohoo. 2009. Invited review: Use of meta-analysis in animal health and reproduction: methods and applications. J. Dairy Sci. 92:3545-3565.

Mantel, N., and W. Haenszel. 1959. Statistical aspects of the analysis of data from retrospective studies of disease. J. Natl. Cancer Inst. 22:719-748.

McKay, B. J., N. Day, M. T. Socha, D. J. Tomlison, and A. B. Johnson. 2002 Effect of feeding complexed zinc, manganese, copper and cobalt to intensively grazed lactating dairy cattle on the north Island of New Zealand. Report to Zinpro Corporation, New Zealand.

Monardes, D., A. R. Melton, I. D. Peeler, J. H. Bame, O. A Peralta, W. S. Swecker, R. L. Nebel, and D. J. Tomlinson. 2002. Supplementing transition cows with organic trace minerals or calcium propionate-propylene glycol drenching: Implications for reproductive performance. J. Dairy Sci. 8(Suppl.1):1058.

Nocek, J. E., A. B. Johnson, and M. T. Socha. 2000. Digital characteristics in commercial dairy herds fed metal-specific amino acid complexes. J. Dairy Sci. 83:1553-1572.

Nocek, J. E., A. B. Socha, and D. J. Tomlinson. 2006. The effect of trace mineral fortification level and source on performance of dairy cattle. J. Dairy Sci. 89:2679-2693.

NRC. 2001. Minerals. Pages 105-161 in Nutrient Requirements of Dairy Cattle. 7th rev. ed. National Research Council, Washington DC.

Peters, J. L., A. J. Sutton, D. R. Jones, K. R. Abrams, and L. Rushton. 2008. Contour-enhanced meta-analysis funnel plots help distinguish publication bias from other causes of asymmetry. J. Clin. Epidemiol. 61:991-996.

Phillippo, M., W. R. Humphries, T. Atkinson, G. D. Henderson, and P. H. Garthwaite. 1987. The effect of dietary molybdenum and iron on copper status, puberty, fertility and oestrous cycles in cattle. J. Agric. Sci. Camb. 109:321-336.

Sanchez, J., I. Dohoo, J. Carrier, and L. DesCoteaux. 2004. A metaanalysis of the milk-production response after anthelmintic treatment in naturally infected adult dairy cows. Prev. Vet. Med. $63: 237-256$

Scaletti, R. W., D. S. Trammell, B. A. Smith, and R. J. Harmon. 2003. Role of dietary copper in enhancing resistance to Escherichia coli mastitis. J. Dairy Sci. 86:1240-1249.

Siciliano-Jones, J. L., M. T. Socha, D. J. Tomlinson, and J. M. DeFrain. 2008. Effect of trace mineral source on lactation performance, claw integrity, and fertility of dairy cattle. J. Dairy Sci. 91:19851995.

Sneed, S. L., J. E. Tomlinson, B. L. Clark, E. J. Murphy, M. E. Boyd, and D. J. Tomlinson. 2001. Lactational and reproductive responses of early lactation Holstein cows to varied levels of dietary supplementation of organic cobalt, copper, manganese and zinc. J. Dairy Sci. 84(Suppl. 1):87.

Starnes, S. R., J. W. Spears, M. A. Froetschel, and W. J. Croom. 1984 Influence of monensin and lasalocid on mineral metabolism and ruminal urease activity in steers. J. Nutr. 114:518-525.

Stephenson, K. A., I. J. Lean, M. L. Hyde, M. A. Curtis, J. K. Garvin, and L. B. Lowe. 1997. Effects of monensin on the metabolism of periparturient dairy cows. J. Dairy Sci. 80:830-837.

Tobias, A. 1999. Assessing the influence of a single study in metaanalysis. Stata Technical Bulletin. 8:108-110.

Toni, F., L. Grigoletto, C. J. Rapp, M. T. Socha, and D. J. Tomlinson. 2007. Effects of replacing dietary inorganic forms of zinc, manganese, and copper with complexed sources on lactation and reproductive performance of dairy cows. Prof. Anim. Sci. 23:409-416.

Uchida, K., P. Mandebvu, C. S. Ballard, C. J. Sniffen, and M. P. Carter. 2001. Effect of feeding a combination of zinc, manganese and copper amino acid complexes, and cobalt glucoheptonate on performance of early lactation high producing dairy cows. Anim. Feed Sci. Technol. 93:193-203.

Van Ryssen, J. B. J. 1991. Effect of monensin and its metabolites in broiler litter on sheep consuming the broiler litter. J. S. Afr. Vet. Med. Assoc. 62:94-99

Yost, G. P., J. D. Arthington, L. R. McDowell, and F. G. Martin. 2002. Effect of copper source and level on the rate and extent of copper repletion in Holstein heifers. J. Dairy Sci. 85:3297-3303. 